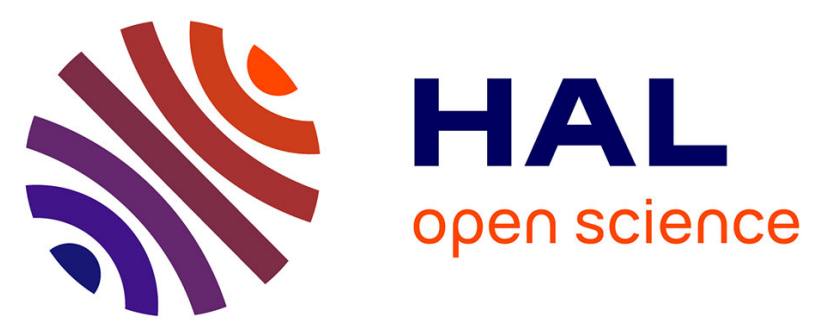

\title{
Validated analytical method to determine new salivary lipid peroxidation compounds as potential neurodegenerative biomarkers
}

Carmen Peña-Bautista, Paula Carrascosa-Marco, Camille Oger, Claire Vigor, Jean-Marie Galano, Thierry Durand, Miguel Baquero, Marina López-Nogueroles, Máximo Vento, Ana García-Blanco, et al.

\section{To cite this version:}

Carmen Peña-Bautista, Paula Carrascosa-Marco, Camille Oger, Claire Vigor, Jean-Marie Galano, et al.. Validated analytical method to determine new salivary lipid peroxidation compounds as potential neurodegenerative biomarkers. Journal of Pharmaceutical and Biomedical Analysis, 2019, 164, pp.742749. 10.1016/j.jpba.2018.11.043 . hal-02417284

\section{HAL Id: hal-02417284 \\ https://hal.science/hal-02417284}

Submitted on 18 Dec 2019

HAL is a multi-disciplinary open access archive for the deposit and dissemination of scientific research documents, whether they are published or not. The documents may come from teaching and research institutions in France or abroad, or from public or private research centers.
L'archive ouverte pluridisciplinaire HAL, est destinée au dépôt et à la diffusion de documents scientifiques de niveau recherche, publiés ou non, émanant des établissements d'enseignement et de recherche français ou étrangers, des laboratoires publics ou privés. 


\title{
Validated analytical method to determine new salivary lipid peroxidation compounds as potential neurodegenerative biomarkers
}

\author{
Carmen Pe ña-Bautista ${ }^{\mathrm{a}}$, Paula Carrascosa-Marco ${ }^{\mathrm{a}}$, Camille Oger ${ }^{\mathrm{b}}$, Claire Vigor ${ }^{\mathrm{b}}$, \\ Jean-Marie Galano ${ }^{\mathrm{b}}$, Thierry Durand ${ }^{\mathrm{b}}$, Miguel Baquero ${ }^{\mathrm{c}}$, Marina López-Nogueroles ${ }^{\mathrm{d}}$, \\ Máximo Vento ${ }^{\mathrm{a}}$, Ana García-Blanco ${ }^{\mathrm{a}, *}$, Consuelo Cháfer-Pericás ${ }^{\mathrm{a}, *}$ \\ a Neonatal Research Unit, Health Research Institute La Fe, Valencia, Spain \\ ${ }^{\mathrm{b}}$ Institut des Biomolécules Max Mousseron (IBMM), UMR 5247 - CNRS - University of Montpellier - ENSCM, Faculty of Pharmacy, Montpellier, France \\ c Neurology Unit, University and Polytechnic Hospital La Fe, Valencia, Spain \\ ${ }^{\mathrm{d}}$ Analytical Unit Platform, Health Research Institute La Fe, Valencia, Spain
}

\section{A B S T R A C T}

Lipid peroxidation is closely related to neurodegenerative diseases since brain shows high lipid com-position and oxygen consumption. The determination of lipid peroxidation compounds in non-invasive biological samples would help to monitor the patients' oxidative stress status. A new analytical method based on ultrasound-assisted liquid-liquid semi-microextraction (UA-LLsME) followed by Ultra Perfor-mance Liquid Chromatography coupled to tandem Mass Spectrometry was developed to determine 18 lipid peroxidation biomarkers in saliva samples. The variables affecting the UA-LLsME efficiency were systematically studied. Under the optimum conditions, the methodology was validated and showed highthroughput, high sensitivity (limits of detection $0.02-2 \mathrm{nmol} \mathrm{L}^{-1}$ ), and satisfactory precision (coef-ficients of variation $2-11 \%$ (intra-day) and $5-12 \%$ (inter-day)). The reliability of the described method was assessed analysing spiked saliva samples, and the recoveries were between $80 \%$ and $120 \%$ for most of the analytes. Then, the method suitability was demonstrated by analysing saliva samples $(n=30)$ from elderly people with neurodegenerative diseases. To conclude, the new developed analytical method is a useful tool to determine salivary lipid peroxidation compounds as potential biomarkers in further clinical studies in which oxidative stress plays an important role.

Keywords:

Liquid-liquid microextraction

saliva

Isoprostanes

Lipid peroxidation

Mass spectrometry

\section{Introduction}

Oxidative stress is a physiological process that increases with aging and under some pathological conditions [1]. Specifically, lipid peroxidation is closely related to neurodegenerative diseases since brain shows high oxygen consumption and high lipid composition [2,3]. Although blood is considered the best biofluid to evaluate it at systemic level, the employment of non-invasively obtained samples would help to monitor the oxidation status [4]. So saliva is considered a promising matrix in clinical studies [5]. In this sense, the validation of an analytical method to determine some lipid peroxidation biomarkers in saliva samples is required.

* Corresponding authors at: Health Research Institute La Fe, Avda de Fernando Abril Martorell, 106, 46026 Valencia, Spain.

E-mail addresses: ana.garcia-blanco@uv.es (A. García-Blanco), m.consuelo.chafer@uv.es (C. Cháfer-Pericás).
Recent studies have used saliva sample to determine oxidative stress biomarkers related to some systemic diseases [6,7]. The clinical relevancy of saliva is based on the fact that its components can be found in plasma $[8,9]$. However, salivary compounds levels may be altered by circadian rhythm and oral conditions [10,11], and few correlation studies between blood and saliva levels can be found in literature [12,13].

Some analytical methods have been developed to study salivary oxidative stress biomarkers (glutathione peroxidase, catalase, protein carbonyls, 8-hydroxy-2'-deoxyguanosine), but few of them determined lipid peroxidation compounds, such as malondialdehyde (MDA) [14-16], and prostanoids (e.g. 15-F 2 -IsoP) [10]. In general, these methods are based on colorimetric assays and immunoassays [4,17-19], but also liquid chromatography (LC) coupled to mass spectrometry (MS) [10,20], or fluorescence detection methods [18] are used. Nevertheless, they have not been validated, so there is a lack of reliable analytical methods.

Suitable saliva sample treatment is crucial in order to obtain an analytical method with satisfactory sensitivity and selectiv- 
Table 1

Demographic and clinical characteristics of the studied population $(n=30)$.

\begin{tabular}{|c|c|c|}
\hline \multicolumn{2}{|l|}{ Age (years) } & $69 \pm 6$ \\
\hline \multicolumn{2}{|l|}{ Gender (female, $\mathrm{n}(\%)$ ) } & $18(53 \%)$ \\
\hline \multirow{4}{*}{ Studies level (n (\%)) } & Basic & $11(32 \%)$ \\
\hline & Primary & $8(24 \%)$ \\
\hline & Secondary & $6(18 \%)$ \\
\hline & Academic & $9(26 \%)$ \\
\hline \multicolumn{2}{|c|}{ Alcohol consumption (Yes, $\mathrm{n}(\%)$ ) } & $5(15 \%)$ \\
\hline \multirow{5}{*}{ Smoking status (n (\%)) } & Yes & $7(21 \%)$ \\
\hline & Former smoker (more than 10 years) & $5(15 \%)$ \\
\hline & Antiaggregants & $1(3 \%)$ \\
\hline & Corticoids & $1(3 \%)$ \\
\hline & Acetyl cholinesterase inhibitors & $4(12 \%)$ \\
\hline \multirow[t]{4}{*}{ Medications (n, (\%)) } & Two or more & $10(29 \%)$ \\
\hline & Psychotropic drugs & $2(6 \%)$ \\
\hline & Others & $7(21 \%)$ \\
\hline & None & $9(26 \%)$ \\
\hline \multicolumn{2}{|l|}{ Depression (Yes, n (\%)) } & $4(12 \%)$ \\
\hline \multirow{6}{*}{ Comorbidity (n (\%)) } & None & $7(205 \%)$ \\
\hline & Dyslipidaemia & $4(12 \%)$ \\
\hline & Arterial hypertension & $7(205 \%)$ \\
\hline & Heart disease & $1(3 \%)$ \\
\hline & Two or more & $10(20 \%)$ \\
\hline & Others & $5(15 \%)$ \\
\hline \multicolumn{2}{|c|}{ Leukocytes $\left(\times 10^{3}\right.$ cells $\left.\mathrm{mm}^{-3}\right)$} & $7.08 \pm 2.29$ \\
\hline \multicolumn{2}{|c|}{ Lymphocytes ( $\mathrm{x} 10^{3}$ cells $\mathrm{mm}^{-3}$ ) } & $2.49 \pm 1.26$ \\
\hline
\end{tabular}

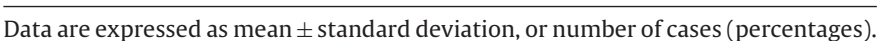
CSF: cerebrospinal fluid sample.

ity. Among potential techniques, the liquid-liquid microextraction (LLME) allows simultaneous pre-concentration and clean-up steps, with the advantages of low solvent volume consumption, simplicity, and low cost. Nevertheless, few works have applied this technique to saliva samples [21]. The main LLME modes are singledrop microextraction [21], hollow-fiber liquid microextraction [22], and dispersive liquid-liquid microextraction [23]. However, their disadvantages are drop instability, solvents toxicity and nonexhaustive extractions. Recent efforts to solve these drawbacks were based on ultrasound, vortex or salt assisted extraction [24,25], but they have not been applied to saliva samples.

In this work, we have developed a reliable analytical method to determine a new set of salivary compounds reflecting lipid peroxidation. For this, a new sample treatment based on ultrasoundassisted liquid-liquid semimicroextraction (UA-LLsME) and the conditions for ultra-performance liquid chromatography-tandem mass spectrometry (UPLC-MS/MS) were optimized. Therefore, this validated analytical method would constitute a useful tool for lipid peroxidation evaluation in further clinical studies.

\section{Materials and methods}

\subsection{Samples collection, and storage}

Saliva samples from participants diagnosed with neurodegenerative diseases (frontotemporal dementia, vascular dementia, Alzheimer's disease) $(n=30)$ were taken at the Neurology Unit (University and Polytechnic Hospital La Fe, Valencia (Spain)) [26]. The participants were between 50 and 75 years old. The study protocol and informed consent from all the participants were approved by the Ethics Committee (CEIC) at the Health Research Institute La Fe (Valencia). Table 1 shows the demographic and clinical characteristics of participants.

Saliva samples were collected by spitting into sterile bottles (between 10 and 12 a.m.). Participants rinsed their mouth before saliva collection. Then, the samples were aliquoted into $1.5 \mathrm{~mL}$ tubes, and those with visible blood contamination were excluded from the study. Finally, samples were stored at $-80^{\circ} \mathrm{C}$ until analysis.

\subsection{Reagents}

Some compounds were acquired from Cayman Chemical Company (Ann Arbor, Michigan, USA) ( $\mathrm{PGE}_{2}, \mathrm{PGF}_{2 \alpha}, 1 \mathrm{a}, 1 \mathrm{~b}-$ dihomo$\mathrm{PGF}_{2 \alpha}$, 5- $\mathrm{F}_{2 \mathrm{t}}$-IsoP, 15- $\mathrm{E}_{2 \mathrm{t}}$-IsoP, 15- $\mathrm{F}_{2 \mathrm{t}}$-IsoP, 15-keto-15-E $\mathrm{E}_{2 \mathrm{t}}$-IsoP, 15-keto-15- $\mathrm{F}_{2 \mathrm{t}}$-IsoP, $15(R)-15-\mathrm{F}_{2 \mathrm{t}}$-IsoP, 2,3-dinor-15-epi-15- $\mathrm{F}_{2 \mathrm{t}}$ IsoP, $\left.\mathrm{PGF}_{2 \alpha}-\mathrm{D}_{4}\right)$ and used as analytes, as in a previous study [27]. Other compounds nor available commercially were synthesized (( $4(R S)-\mathrm{F}_{4 \mathrm{t}}$-NeuroP, 7(RS)-ST- $\Delta^{8}$-11-dihomo-IsoF, Ent-7(RS)-

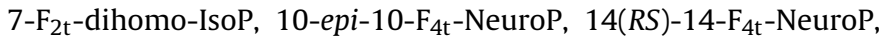
17-epi-17- $\mathrm{F}_{2 \mathrm{t}}$-dihomo-IsoP, 17- $\mathrm{F}_{2 \mathrm{t}}$-dihomo-IsoP, 17(RS)-10-epiSC- $\Delta^{15}$-11-dihomo-IsoF, $\mathrm{D}_{4}-10-e p i-10-\mathrm{F}_{4 \mathrm{t}}$-NeuroP) [28], and they were used as analytes, as in previous studies $[29,30]$.

Methanol $\left(\mathrm{CH}_{3} \mathrm{OH}\right.$, HPLC grade), acetonitrile $\left(\mathrm{CH}_{3} \mathrm{CN}\right.$, HPLC grade), and glacial acetic acid were from J.T. Baker (Avantor Performance Materials B.V., The Netherlands). Ethyl acetate (analytical grade) was from Panreac (Barcelona, Spain). Protein assay kit (Pierce $^{\mathrm{TM}}$ BCA) was purchased from Thermo Scientific (Rockford, USA).

\subsection{Solutions}

Stock standard solutions of each compound were prepared at $1 \mathrm{mmol} \mathrm{L}^{-1}$ in $\mathrm{H} 2 \mathrm{O}(\mathrm{CH} 3 \mathrm{COOH} 0.01 \%, \mathrm{v} / \mathrm{v}): \mathrm{CH} 3 \mathrm{OH}(85: 15 \mathrm{v} / \mathrm{v})$. A mix working solution was prepared in $\mathrm{H} 2 \mathrm{O}(\mathrm{CH} 3 \mathrm{COOH} 0.01 \%$, $\mathrm{v} / \mathrm{v}): \mathrm{CH} 3 \mathrm{OH}(85: 15 \mathrm{v} / \mathrm{v})\left(2.5 \mu \mathrm{mol} \mathrm{L}^{-1}\right.$ each analyte $)$. The calibration curves were prepared in $\mathrm{H} 2 \mathrm{O}(\mathrm{CH} 3 \mathrm{COOH} 0.01 \%, \mathrm{v} / \mathrm{v}): \mathrm{CH} 3 \mathrm{OH}(85: 15$ $\mathrm{v} / \mathrm{v})\left(0.004 \mathrm{nmol} \mathrm{L}-1-300 \mathrm{nmol} \mathrm{L}^{-1}\right.$, each analyte) as described in a previous work [29].

\subsection{Materials}

The ultrasonic bath (Sonorex Digitec) was from Bandelin (Berlin, Germany), the centrifuge (multiSPIN) from Cleaver Scientific Ltd. (Warwickshire, United Kingdom), and the vortex mixer from Velp Scientifica (Usmate, Italy). The thermomixer HLC was from Ditabis (Pforzheim, Germany), the speed vacuum concentrator (mi Vac) from Genevac LTD (Ipswich, United Kingdom), and the spectrophotometer (Halo LED 96) from Dynamica Scientific Ltd. (London, United Kingdom).

\subsection{UPLC-MS/MS chromatographic system}

The chromatographic system used consisted of an Acquity UPLC system coupled to a Xevo TQ-S mass spectrometer (MS) (Waters, UK). The MS detector consisted of an electrospray ionization source working in the negative mode (ESI-) and multiple reaction monitoring (MRM) mode. The UPLC-MS/MS system conditions were described in a previous work [30]. Briefly, the LC conditions were an Acquity UPLC BEH C18 column, $\mathrm{H} 2 \mathrm{O}$ and $\mathrm{CH} 3 \mathrm{CN}$ with $0.01 \% \mathrm{v} / \mathrm{v}$ $\mathrm{CH} 3 \mathrm{COOH}$ as mobile phases, $55^{\circ} \mathrm{C}$ and $4{ }^{\circ} \mathrm{C}$ as column and autosampler temperatures, $8 \mu \mathrm{L}$ as injection volume, and $0.45 \mathrm{~mL} \mathrm{~min}{ }^{-1}$ as flow rate; and the detection conditions were $2.0 \mathrm{kV}$ as capillary voltage, $150^{\circ} \mathrm{C}$ and $395^{\circ} \mathrm{C}$ as source and desolvation temperatures, $150 \mathrm{~L} \mathrm{~h}^{-1}$ and $800 \mathrm{~L} \mathrm{~h}^{-1}$ as nitrogen cone and desolvation gas flows, and $10 \mathrm{~ms}$ as dwell time.

\subsection{Saliva sample treatment}

Saliva samples were thawed on ice, homogenized and centrifuged at $3500 \mathrm{~g}\left(10 \mathrm{~min}, 4^{\circ} \mathrm{C}\right)$ in order to determine analytes in supernatant. The saliva sample treatment was optimized from a previous work with new-borns' saliva samples [31]. First, $150 \mu \mathrm{L}$ of saliva sample were diluted with $450 \mu \mathrm{L}$ of $\mathrm{H}_{2} \mathrm{O}(0.01 \%(\mathrm{v} / \mathrm{v})$ acetic acid), and $5 \mu \mathrm{L}$ of internal standard (IS) solution $\left(\mathrm{PGF}_{2 \alpha}-\mathrm{D}_{4} 2 \mu \mathrm{mol}\right.$ $\mathrm{L}^{-1}$ and $\mathrm{D}_{4}-10$-epi-10- $\mathrm{F}_{4 \mathrm{t}}-\mathrm{NeroP} 1.2 \mu \mathrm{mol} \mathrm{L}^{-1}$ ) were added to each 
Table 2

Mass spectrometry detection parameters.

\begin{tabular}{|c|c|c|c|c|c|c|}
\hline \multirow{2}{*}{ Analyte } & \multirow{2}{*}{$\mathrm{m} / \mathrm{z}$ Precursor Ion } & \multirow{2}{*}{ Cone [V] } & \multicolumn{4}{|l|}{$\mathrm{m} / \mathrm{z}$ Product Ion } \\
\hline & & & Quantification & $\mathrm{CE}[\mathrm{eV}]$ & Confirmation & $\mathrm{CE}[\mathrm{eV}]$ \\
\hline $15(R)-15-\mathrm{F}_{2 \mathrm{t}}-\mathrm{IsoP}$ & 353.2 & 40 & 193.1 & 25 & 309.2 & 20 \\
\hline 2,3-dinor-15-epi-15- $\mathrm{F}_{2 \mathrm{t}}$-IsoP & 325.2 & 20 & 237 & 10 & - & - \\
\hline 15-keto-15- $\mathrm{E}_{2 \mathrm{t}}-\mathrm{IsoP}$ & 349.2 & 20 & 331 & 15 & 235 & 15 \\
\hline 15-keto-15-F2t-IsoP & 351.2 & 30 & 315.1 & 15 & 289 & 20 \\
\hline $\mathrm{PGE}_{2}$ & 351.2 & 40 & 271 & 20 & 315.1 & 15 \\
\hline $15-E_{2 t}-$ IsoP & 351.2 & 40 & 271 & 20 & 315.1 & 15 \\
\hline $15-\mathrm{F}_{2 \mathrm{t}}$-IsoP & 353.2 & 40 & 193.1 & 25 & 309.2 & 20 \\
\hline $\mathrm{PGF}_{2 \alpha}$ & 353.2 & 40 & 309.2 & 20 & 193.1 & 25 \\
\hline $5-\mathrm{F}_{2 \mathrm{t}}-\mathrm{IsoP}$ & 353.2 & 30 & 114.8 & 20 & 309.2 & 20 \\
\hline 1a,1b-dihomo-PGF $2 \alpha$ & 381.2 & 40 & 337 & 20 & 319.1 & 25 \\
\hline $\mathrm{PGF}_{2 \alpha}-\mathrm{D}_{4}$ & 357.2 & 20 & 313.1 & 20 & - & - \\
\hline $7(R S)$-ST- $\Delta^{8}$-11-dihomo-IsoF & 397.2 & 20 & 200.9 & 25 & 148.8 & 25 \\
\hline 10-epi-10-F $\mathrm{F}_{4 \mathrm{t}}-\mathrm{NeuroP}$ & 377.1 & 10 & 152.9 & 20 & 109.8 & 20 \\
\hline $\mathrm{D}_{4}-10-$ epi-10-F $\mathrm{F}_{4 \mathrm{t}}-$ NeuroP & 381.2 & 20 & 157 & 20 & - & - \\
\hline 17-epi-17-F $\mathrm{F}_{2 \mathrm{t}}$-dihomo-IsoP & 381.2 & 30 & 337 & 20 & 319.1 & 20 \\
\hline $17-\mathrm{F}_{2 \mathrm{t}}$-dihomo-IsoP & 381.2 & 30 & 337 & 20 & 319.1 & 20 \\
\hline $17(R S)$-10-epi-SC- $\Delta^{15}$-11-dihomo-IsoF & 397.2 & 10 & 154.9 & 30 & 220.9 & 25 \\
\hline Ent-7(RS)-7- $\mathrm{F}_{2 \mathrm{t}}$-dihomo-IsoP & 381.2 & 30 & 142.9 & 20 & 363.2 & 15 \\
\hline $14(R S)-14-\mathrm{F}_{4 \mathrm{t}}-$ NeuroP & 377.1 & 40 & 205 & 15 & 271 & 20 \\
\hline $4(R S)-\mathrm{F}_{4 \mathrm{t}}-$ NeuroP & 377.1 & 20 & 100.8 & 20 & 271 & 20 \\
\hline NeuroPs & 377 & 35 & 101 & 20 & - & - \\
\hline IsoPs & 353.2 & 40 & 115 & 20 & - & - \\
\hline NeuroFs & 393 & 35 & 193 & 20 & - & - \\
\hline IsoFs & 369.2 & 45 & 115 & 20 & - & - \\
\hline
\end{tabular}

sample. Then, $600 \mu \mathrm{L}$ of ethyl acetate were added to each sample and it was sonicated for $10 \mathrm{~min}$. After that, samples were placed at $-20^{\circ} \mathrm{C}$ for $30 \mathrm{~min}$ to improve both phases separation. The organic phase was collected in a new tube and the UA-LLsME was repeated to enhance the analytes extraction from the aqueous phase. Finally, both ethyl acetate layers $(600 \mu \mathrm{L} \times 2)$ were joined and evaporated to dryness in the speed vacuum concentrator. The residues were reconstituted in $100 \mu \mathrm{L}$ of $\mathrm{H}_{2} \mathrm{O}: \mathrm{CH}_{3} \mathrm{OH}(85: 15(\mathrm{v} / \mathrm{v}), 0.01 \%$ acetic acid) and injected in the chromatographic system (UPLC-MS/MS).

The same sample treatment was applied to standards (prepared in $\mathrm{H}_{2} \mathrm{O}$ containing $0.01 \%(\mathrm{v} / \mathrm{v})$ acetic acid) in order to take into account the procedure effect over some analytes obtaining a reliable quantification in real samples.

\subsection{Method validation}

For the method validation some analytical characteristics were evaluated for each analyte (limits of quantification (LOQ), limits of detection (LOD), linearity, precision, accuracy, matrix effect, stability). The LODs and LOQs, defined as the standard concentrations generating a signal-to-noise ratio of 3 and 10, respectively, as well as the linearity were evaluated in a previous study [30]. Then, saliva samples non-spiked and spiked at three concentration levels (i.e. low, mid, and high) were analyzed at three different days to evaluate the precision and accuracy. The matrix effect for each analyte in saliva was evaluated comparing the added concentrations (X) with the found concentrations using the proposed method $(\mathrm{Y})$ by means of a linear regression. Finally, the analytes' stability in spiked saliva samples was assayed under different storage conditions (one, two or three freeze-thaw cycles, and $24 \mathrm{~h}$ at $4{ }^{\circ} \mathrm{C}$ ).

\subsection{Analysis of saliva samples}

Collected saliva samples were kept at $-80^{\circ} \mathrm{C}$ until analysis. The suitability of the developed analytical method was evaluated by analysing these real samples. In this way, the concentrations ranges obtained for each analyte in saliva samples from patients were determined. To standardize the results in saliva samples, protein levels were determined using a colorimetric protein assay kit (Pierce $^{\mathrm{TM}}$ BCA) and measuring in a spectrophotometer.

\subsection{Statistical analysis}

Univariate statistical analyses were performed using SPSS version 20.0 software (SPSS, Inc., Chicago, IL, USA). For all analyses, the statistical significance was set at $p<0.05$.

\section{Results and discussion}

\subsection{Optimization of the UA-LLSME procedure}

The main challenge of saliva pretreatment is the efficient extraction of target analytes and the subsequent clean-up step to remove matrix interferences. In this sense, the developed saliva treatment procedure allows carrying out simultaneously the extraction and clean-up steps. It consists of UA-LLsME, in which a low-density extraction solvent is dispersed into aqueous phase using ultrasonication. Some parameters involved in extraction efficiency were systematically studied, including the sample volume, sample $\mathrm{pH}$, volume of extraction solvent, number of liquid-liquid extraction steps, ultrasonication time and salting-out effect.

First, taking into account the limited saliva volumes available in neurodegenerative disease patients, small sample volumes were assayed between 50 and $150 \mu \mathrm{L}$ of spiked saliva sample $(100 \mathrm{nmol}$ $\mathrm{L}^{-1}$ for each analyte). Satisfactory recoveries were obtained in all the cases. However, according to the low concentrations found for $5-\mathrm{F}_{2 \mathrm{t}}$-IsoP and $15-\mathrm{F}_{2 \mathrm{t}}$-IsoP in saliva [10], $150 \mu \mathrm{L}$ was selected as the optimum volume.

The effect of sample $\mathrm{pH}$ was evaluated between 3 and 7 using $150 \mu \mathrm{L}$ of spiked sample. Higher recoveries were obtained at $\mathrm{pH} 3$. It was achieved by diluting the sample with $450 \mu \mathrm{L}$ of $\mathrm{H}_{2} \mathrm{O}(0.01 \%$ $(\mathrm{v} / \mathrm{v})$ acetic acid), since the analytes were in their neutral form $\left(\mathrm{pK}_{\mathrm{a}}\right.$ $>3$ ) and their extraction into a non-polar solvent was more efficient. Consequently, the sample $\mathrm{pH}$ was adjusted to 3 before the analysis.

As regards the extraction solvent, a non-polar and low density solvent was required in order to improve the analytes extraction efficiency minimizing the interferences. Among the potential solvents and taking into account their toxicity, ethyl acetate was considered a suitable extraction solvent and all further experiments were carried out with it. 

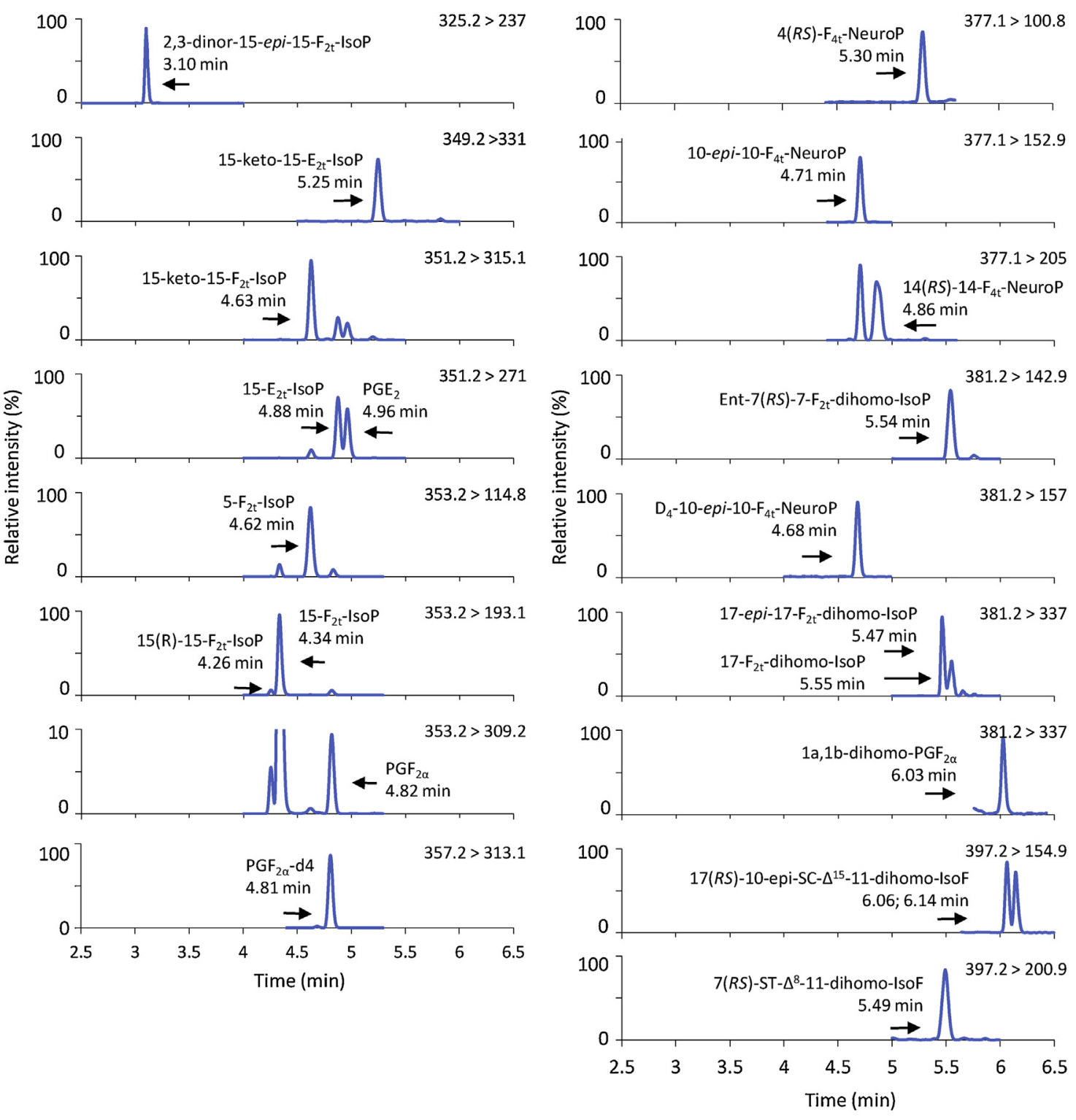

Fig. 1. Chromatograms (MRM transition used for quantification) obtained by the UPLC-MS/MS method for a mix standard solution of 100 nmol $\mathrm{L}^{-1}$ of each analyte.

After that, the influence of the extraction solvent volume $(600-1200 \mu \mathrm{L})$ and the number of liquid-liquid extraction steps (1-2) were evaluated simultaneously. For this, $150 \mu \mathrm{L}$ of spiked saliva ( $100 \mathrm{nmol} \mathrm{L}^{-1}$ of each compound), adjusted to $\mathrm{pH} \mathrm{3}$, and 10 min of sonication were used. Recoveries were close to $100 \%$ for most of the analytes by means of two LLE steps and $1200 \mu \mathrm{L}$ $(2 \times 600 \mu \mathrm{L})$ of ethyl acetate, therefore these conditions were selected as optimum.

Different sonication times in the 1-15 min interval were tested under the previous selected conditions. In general, all the analytes increased their analytical signal by extending the sonication time up to $10 \mathrm{~min}$, little improvement was observed for longer times. Therefore, a sonication time of $10 \mathrm{~min}$ was set for each liquid-liquid extraction step.

Finally, the salting out effect was assayed by adding a sodium chloride solution $\left(2 \mathrm{~mol} \mathrm{~L}^{-1}\right)$ to the aqueous phase to improve the analytes extraction into the organic phase [32]. Nevertheless, recoveries were similar to those obtained without the salt addition, so it was not added in further experimental work.

In summary, the optimum saliva treatment conditions were $150 \mu \mathrm{L}$ of sample volume, adjusted at $\mathrm{pH} 3$, a two-step liquid- liquid extraction with $2 \times 600 \mu \mathrm{L}$ of ethyl acetate as extraction solvent total volume, and $10 \mathrm{~min}$ of sonication time. Under optimized conditions, the extraction yield was considered quantitative for most of the analytes, with recoveries ranging from 80 to $120 \%$.

As regards the sample treatment effect over analytes in standards prepared in $\mathrm{H}_{2} \mathrm{O}(0.01 \%$ (v/v) acetic acid), a significant signal increase was observed for 17-epi-17- $\mathrm{F}_{2 \mathrm{t}}$-dihomo-IsoP, $17-\mathrm{F}_{2 \mathrm{t}}$-dihomo-IsoP, $17(R S)-10$-epi-SC- $\Delta^{15}$-11-dihomo-IsoF and $1 \mathrm{a}, 1 \mathrm{~b}-$ dihomo-PGF $2 \alpha$. Probably, these analytes which are characterized by higher $m / z$ parent ion could experiment a significant enhancement of ionization under the higher concentration of acetate ions provided by sample treatment [33]. Therefore, the concentrations of these analytes in saliva samples were quantified using the calibration equations obtained with standard solutions subjected to the same sample treatment.

\subsection{Optimization of the UPLC-MS/MS conditions}

Transitions, cone voltages, and collision energies for the detection were automatically tuned for each analyte using the 
Table 3

Analytical characteristics of the UPLC-MS/MS developed method.

\begin{tabular}{|c|c|c|c|c|c|}
\hline \multirow{2}{*}{ Analyte } & \multirow[b]{2}{*}{$\begin{array}{l}\text { Retention time }{ }^{a} \\
(\mathrm{~min})\end{array}$} & \multicolumn{2}{|l|}{ Linearity } & \multirow{2}{*}{$\begin{array}{l}\mathrm{LOD}^{c} \\
\left(\mathrm{nmol} \mathrm{L}^{-1}\right)\end{array}$} & \multirow{2}{*}{$\begin{array}{l}\mathrm{LOQ}^{c} \\
\left(\mathrm{nmol} \mathrm{L}^{-1}\right)\end{array}$} \\
\hline & & $\begin{array}{l}\text { Linear interval } \\
\left(\mathrm{nmol} \mathrm{L}^{-1}\right)\end{array}$ & Calibration equation $^{\mathrm{b}} \mathrm{y}=\mathrm{a}+\mathrm{bx}$ & & \\
\hline 2,3-dinor-15-epi-15- $\mathrm{F}_{2 \mathrm{t}}$-IsoP & $3.093 \pm 0.004$ & $0.07-150$ & $\begin{array}{l}\mathrm{a} \pm \mathrm{s}_{\mathrm{a}}=1.04 \pm 0.8 ; \mathrm{b} \pm \mathrm{s}_{\mathrm{b}}=1.41 \pm 0.01 \\
\mathrm{R}^{2}=0.999(\mathrm{n}=10)\end{array}$ & 0.02 & 0.07 \\
\hline 15-keto-15-F $\mathrm{F}_{2 \mathrm{t}}$-IsoP & $4.631 \pm 0.003$ & $0.14-150$ & $\begin{array}{l}a \pm s_{a}=-12.469 \pm 9.613 ; b \pm s_{b}=2.247 \pm 0.149 \\
R^{2}=0.990(n=8)\end{array}$ & 0.05 & 0.14 \\
\hline $15(R)-15-\mathrm{F}_{2 \mathrm{t}}$-IsoP & $4.263 \pm 0.004$ & $0.07-150$ & $\begin{array}{l}\mathrm{a} \pm \mathrm{s}_{\mathrm{a}}=0.284 \pm 0.334 ; \mathrm{b} \pm \mathrm{s}_{\mathrm{b}}=0.913 \pm 0.005 \\
\mathrm{R}^{2}=0.999(\mathrm{n}=10)\end{array}$ & 0.02 & 0.07 \\
\hline 15-keto-15-E 2 -IsoP & $5.254 \pm 0.005$ & $0.28-150$ & $\begin{array}{l}\mathrm{a} \pm \mathrm{s}_{\mathrm{a}}=0.075 \pm 0.185 ; \mathrm{b} \pm \mathrm{s}_{\mathrm{b}}=1.205 \pm 0.003 \\
\mathrm{R}^{2}=0.999(\mathrm{n}=8)\end{array}$ & 0.1 & 0.3 \\
\hline $\mathrm{PGE}_{2}$ & $4.957 \pm 0.004$ & $0.28-150$ & $\begin{array}{l}\mathrm{a} \pm \mathrm{s}_{\mathrm{a}}=-0.912 \pm 0.570 ; \mathrm{b} \pm \mathrm{s}_{\mathrm{b}}=1.442 \pm 0.009 \\
\mathrm{R}^{2}=0.999(\mathrm{n}=8)\end{array}$ & 0.1 & 0.3 \\
\hline $15-E_{2 t}-$ IsoP & $4.876 \pm 0.003$ & $0.28-150$ & $\begin{array}{l}\mathrm{a} \pm \mathrm{s}_{\mathrm{a}}=-0.643 \pm 0.4 ; \mathrm{b} \pm \mathrm{s}_{\mathrm{b}}=1.794 \pm 0.005 \\
\mathrm{R}^{2}=0.999(\mathrm{n}=8)\end{array}$ & 0.1 & 0.3 \\
\hline $15-\mathrm{F}_{2 \mathrm{t}}-\mathrm{IsoP}$ & $4.34 \pm 0.01$ & $0.07-150$ & $\begin{array}{l}a \pm s_{a}=167.37 \pm 38.68 ; b \pm s_{b}=18.56 \pm 0.33 \\
R^{2}=0.998(n=10)\end{array}$ & 0.02 & 0.07 \\
\hline $\mathrm{PGF}_{2 \alpha}$ & $4.816 \pm 0.004$ & $0.07-150$ & $\begin{array}{l}\mathrm{a} \pm \mathrm{s}_{\mathrm{a}}=6.5 \pm 2.911 ; \mathrm{b} \pm \mathrm{s}_{\mathrm{b}}=3.06 \pm 0.025 \\
\mathrm{R}^{2}=0.999(\mathrm{n}=10)\end{array}$ & 0.02 & 0.07 \\
\hline 7(RS)-ST- $\Delta^{8}$-11-dihomo-IsoF & $5.491 \pm 0.003$ & $0.12-135$ & $\begin{array}{l}\mathrm{a} \pm \mathrm{s}_{\mathrm{a}}=-0.826 \pm 0.549 ; \mathrm{b} \pm \mathrm{s}_{\mathrm{b}}=0.540 \pm 0.009 \\
\mathrm{R}^{2}=0.999(\mathrm{n}=8)\end{array}$ & 0.04 & 0.12 \\
\hline $5-\mathrm{F}_{2 \mathrm{t}}$-IsoP & $4.616 \pm 0.004$ & $0.07-150$ & $\begin{array}{l}\mathrm{a} \pm \mathrm{s}_{\mathrm{a}}=2.042 \pm 0.642 ; \mathrm{b} \pm \mathrm{s}_{\mathrm{b}}=0.754 \pm 0.005 \\
\mathrm{R}^{2}=0.999(\mathrm{n}=9)\end{array}$ & 0.02 & 0.07 \\
\hline 10-epi-10-F $\mathrm{F}_{4 \mathrm{t}}-\mathrm{NeuroP}$ & $4.71 \pm 0.01$ & $0.1-142$ & $\begin{array}{l}\mathrm{a} \pm \mathrm{s}_{\mathrm{a}}=-7.667 \pm 2.525 ; \mathrm{b} \pm \mathrm{s}_{\mathrm{b}}=2.615 \pm 0.023 \\
\mathrm{R}^{2}=0.999(\mathrm{n}=9)\end{array}$ & 0.03 & 0.1 \\
\hline 17-epi-17-F2t-dihomo-IsoP & $5.47 \pm 0.01$ & $0.13-140$ & $\begin{array}{l}\mathrm{a} \pm \mathrm{s}_{\mathrm{a}}=-0.123 \pm 0.939 ; \mathrm{b} \pm \mathrm{s}_{\mathrm{b}}=2.855 \pm 0.008 \\
\mathrm{R}^{2}=0.999(\mathrm{n}=10)\end{array}$ & 0.04 & 0.13 \\
\hline $17-\mathrm{F}_{2 \mathrm{t}}$-dihomo-IsoP & $5.549 \pm 0.003$ & $0.13-140$ & $\begin{array}{l}\mathrm{a} \pm \mathrm{s}_{\mathrm{a}}=-0.308 \pm 1.029 ; \mathrm{b} \pm \mathrm{s}_{\mathrm{b}}=1.763 \pm 0.009 \\
\mathrm{R}^{2}=0.999(\mathrm{n}=7)\end{array}$ & 0.04 & 0.13 \\
\hline $17(R S)$-10-epi-SC- $\Delta^{15}$-11-dihomo-IsoF & $6.117 \pm 0.04$ & $2-135$ & $\begin{array}{l}\mathrm{a} \pm \mathrm{s}_{\mathrm{a}}=-1.213 \pm 0.457 ; \mathrm{b} \pm \mathrm{s}_{\mathrm{b}}=0.861 \pm 0.004 \\
\mathrm{R}^{2}=0.999(\mathrm{n}=9)\end{array}$ & 0.7 & 2 \\
\hline Ent-7(RS)-7- $\mathrm{F}_{2 \mathrm{t}}$-dihomo-IsoP & $5.536 \pm 0.004$ & $0.07-140$ & $\begin{array}{l}\mathrm{a} \pm \mathrm{s}_{\mathrm{a}}=-1.639 \pm 1.083 ; \mathrm{b} \pm \mathrm{s}_{\mathrm{b}}=1.097 \pm 0.018 \\
\mathrm{R}^{2}=0.999(\mathrm{n}=8)\end{array}$ & 0.02 & 0.07 \\
\hline $14(R S)-14-\mathrm{F}_{4 \mathrm{t}}-\mathrm{NeuroP}$ & $4.86 \pm 0.03$ & $8-142$ & $\begin{array}{l}\mathrm{a} \pm \mathrm{s}_{\mathrm{a}}=0.178 \pm 0.334 ; \mathrm{b} \pm \mathrm{s}_{\mathrm{b}}=0.139 \pm 0.003 \\
\mathrm{R}^{2}=0.997(\mathrm{n}=9)\end{array}$ & 2 & 8 \\
\hline 1a,1b-dihomo-IsoP & $6.03 \pm 0.01$ & $0.28-150$ & $\begin{array}{l}\mathrm{a} \pm \mathrm{s}_{\mathrm{a}}=-7.786 \pm 2.388 ; \mathrm{b} \pm \mathrm{s}_{\mathrm{b}}=1.094 \pm 0.02 \\
\mathrm{R}^{2}=0.998(\mathrm{n}=9)\end{array}$ & 0.1 & 0.28 \\
\hline $4(R S)-\mathrm{F}_{4 \mathrm{t}}-$ NeuroP & $5.296 \pm 0.005$ & $8-142$ & $\begin{array}{l}\mathrm{a} \pm \mathrm{s}_{\mathrm{a}}=-4.11 \pm 1.355 ; \mathrm{b} \pm \mathrm{s}_{\mathrm{b}}=0.56 \pm 0.012 \\
\mathrm{R}^{2}=0.997(\mathrm{n}=8)\end{array}$ & 2 & 8 \\
\hline
\end{tabular}

Quanoptimizer software (Waters) and individual $0.5 \mu \mathrm{g} \mathrm{mL}{ }^{-1}$ standard solutions (Table 2). The data station operating software used was MassLynx 4.1 (Waters).

Regarding chromatographic optimization the mobile phase composition was firstly studied. The modifier acetic acid at $0.01 \%$ $(\mathrm{v} / \mathrm{v})$ was used in the mobile phase in order to improve the analytes ionization in the MS detector. Moreover, acetonitrile and methanol were tested as organic modifiers obtaining better results with acetonitrile. Different combinations of flow rates (from 0.3 to $0.5 \mathrm{~mL}$ $\mathrm{min}^{-1}$ ), column temperatures (from $40^{\circ} \mathrm{C}$ to $60^{\circ} \mathrm{C}$ ) and gradients were tested in order to obtain a satisfactory chromatographic resolution in a run-time as short as possible. The injection volume was studied at two levels ( 4 and $8 \mu \mathrm{L}$ ) and better sensitivity without loss in resolution was obtained when injecting $8 \mu \mathrm{L}$.

Under the optimum conditions, described in Section 2.5, a good chromatographic separation was achieved for the 18 analytes in less than 8 min, as can be seen in Fig. 1.

\subsection{Analytical performance data}

Standards with concentrations between 0.03 and $300 \mathrm{mmol}$ $\mathrm{L}^{-1}$ were used to evaluate the analytical method performance. As shown in Table 3, all compounds showed adequate linearity with R2 between 0.990 and 0.999 , as well as suitable LODs $(0.02-2 \mathrm{nmol}$ $\mathrm{L}^{-1}$ ) and LOQs $\left(0.07-8 \mathrm{nmol} \mathrm{L}^{-1}\right)$ [30]. In general, our results match with those from works in literature [12], allowing the quantification of these analytes at levels normally found in saliva samples [10].
Regarding precision, it was satisfactory for standard solutions (Table 4), and the analysis of spiked saliva samples provided coefficients of variation between 2.5 and $18 \%$ for most of the analytes, higher values corresponded to the inter-day analysis (Table 4). These values were satisfactory $(<20 \%)$ taking into account the several steps required in the sample treatment procedure. The accuracy of the method was evaluated by analyzing saliva samples spiked at three concentration levels (low, medium, and high). They were quantified using external calibration equations and satisfactory recoveries were obtained for all the analytes (Table 4), with the exception of 17-epi-17- $\mathrm{F}_{2 \mathrm{t}}$-dihomo-IsoP, 17- $\mathrm{F}_{2 \mathrm{t}}$-dihomo-IsoP, $17(R S)$-10-epi-SC- $\Delta^{15}$-11-dihomo-IsoF and $1 \mathrm{a}, 1 \mathrm{~b}-$ dihomo-PGF $2 \alpha$. As a possible cause, sample treatment effect was evaluated and significant signals increase was observed for these analytes. Therefore, the use of calibration equations constructed from standard solutions subjected to UA-LLSME sample treatment to quantify these analytes, provided satisfactory recoveries (Table 4). Then, matrix effect was evaluated for each analyte. In all the cases, the slopes corresponding to the linear regressions of added concentrations (X) vs found concentrations $(\mathrm{Y})$ were statistically comparable to 1 (at a confidence level of 95\%), so the matrix effect was considered negligible.

In addition, four total parameters were determined as relative contents of salivary isoprostanes (IsoPs), isofurans (IsoFs), neuroprostanes (NeuroPs) and neurofurans (NeuroFs), they included the sum of isomers from each fatty acid oxidation family. Similarly, these parameters were determined in previous studies carried out in plasma [27] and urine samples [29]. 
Table 4

Accuracy and precision of the analytical method for standard solutions and saliva samples spiked at different concentration levels.

\begin{tabular}{|c|c|c|c|c|c|c|}
\hline \multirow{3}{*}{ Analytes } & \multicolumn{3}{|l|}{ Standard Solutions } & \multicolumn{3}{|l|}{ Spiked saliva samples ${ }^{\mathrm{a}}$} \\
\hline & \multirow{2}{*}{$\begin{array}{l}\text { Standard concentration } \\
(\mathrm{nmol} \mathrm{L} \\
-1)\end{array}$} & \multicolumn{2}{|l|}{$[$ Recovery $\pm \mathrm{s}(\%)]$} & \multirow{2}{*}{$\begin{array}{l}\text { Sample added concentration } \\
\left(\mathrm{nmol} \mathrm{L}^{-1}\right)\end{array}$} & \multicolumn{2}{|l|}{$[$ Recovery $\pm \mathrm{s}(\%)]$} \\
\hline & & Intra-day $(\mathrm{n}=3)$ & Inter-day $(\mathrm{n}=3)$ & & Intra-day $(\mathrm{n}=3)$ & Inter-day $(\mathrm{n}=3)$ \\
\hline \multirow{3}{*}{ 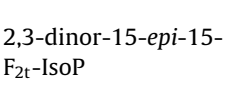 } & 18.7 & $84 \pm 2$ & $110 \pm 6$ & 10 & $72 \pm 2$ & $80 \pm 6$ \\
\hline & 75 & $99 \pm 2$ & $104 \pm 6$ & 50 & $104 \pm 2$ & $90 \pm 9$ \\
\hline & 150 & $93 \pm 2$ & $104 \pm 2$ & 100 & $78 \pm 3$ & $85 \pm 4$ \\
\hline & 18.7 & $89 \pm 3$ & $92 \pm 8$ & 10 & $92 \pm 9$ & $90 \pm 10$ \\
\hline \multirow[t]{3}{*}{ 15-keto-15-F ${ }_{2 t}$-IsoP } & 75 & $108 \pm 7$ & $83 \pm 6$ & 50 & $111 \pm 9$ & $107 \pm 9$ \\
\hline & 150 & $96 \pm 6$ & $115 \pm 10$ & 100 & $100 \pm 10$ & $107 \pm 8$ \\
\hline & 18.7 & $80 \pm 2$ & $117 \pm 10$ & 10 & $114 \pm 9$ & $81 \pm 9$ \\
\hline \multirow{3}{*}{ 15-keto-15-E 2 -IsoP } & 75 & $84 \pm 3$ & $83 \pm 5$ & 50 & $97 \pm 9$ & $80 \pm 10$ \\
\hline & 150 & $116 \pm 3$ & $108 \pm 8$ & 100 & $120 \pm 10$ & $104 \pm 9$ \\
\hline & 18.7 & $107 \pm 8$ & $106 \pm 5$ & 10 & $79 \pm 7$ & $105 \pm 17$ \\
\hline \multirow{3}{*}{$15(R)-15-\mathrm{F}_{2 \mathrm{t}}-\mathrm{IsoP}$} & 75 & $110 \pm 4$ & $94 \pm 7$ & 50 & $101 \pm 12$ & $105 \pm 19$ \\
\hline & 150 & $104 \pm 3$ & $92 \pm 5$ & 100 & $92 \pm 10$ & $85 \pm 8$ \\
\hline & 18.7 & $85 \pm 5$ & $112 \pm 10$ & 10 & $102 \pm 9$ & $93 \pm 6$ \\
\hline \multirow{3}{*}{$\mathrm{PGE}_{2}$} & 75 & $105 \pm 5$ & $90 \pm 7$ & 50 & $112 \pm 3$ & $98 \pm 7$ \\
\hline & 150 & $106 \pm 3$ & $100 \pm 8$ & 100 & $105 \pm 5$ & $104 \pm 17$ \\
\hline & 18.7 & $81 \pm 4$ & $100 \pm 10$ & 10 & $89 \pm 5$ & $95 \pm 10$ \\
\hline \multirow{3}{*}{$15-E_{2 t}-$ IsoP } & 75 & $94 \pm 7$ & $100 \pm 9$ & 50 & $87 \pm 4$ & $94 \pm 8$ \\
\hline & 150 & $99 \pm 6$ & $111 \pm 7$ & 100 & $101 \pm 6$ & $72 \pm 9$ \\
\hline & 18.7 & $100 \pm 5$ & $110 \pm 5$ & 10 & $84 \pm 5$ & $87 \pm 9$ \\
\hline \multirow[t]{3}{*}{$5-\mathrm{F}_{2 \mathrm{t}}-\mathrm{IsoP}$} & 75 & $105 \pm 5$ & $92 \pm 5$ & 50 & $102 \pm 10$ & $100 \pm 7$ \\
\hline & 150 & $97 \pm 5$ & $90 \pm 9$ & 100 & $86 \pm 8$ & $93 \pm 3$ \\
\hline & 18.7 & $110 \pm 6$ & $84 \pm 9$ & 10 & $98 \pm 10$ & $100 \pm 20$ \\
\hline \multirow[t]{3}{*}{$15-\mathrm{F}_{2 \mathrm{t}}-\mathrm{IsoP}$} & 75 & $113 \pm 7$ & $96 \pm 9$ & 50 & $120 \pm 10$ & $99 \pm 19$ \\
\hline & 150 & $94 \pm 4$ & $120 \pm 6$ & 100 & $95 \pm 8$ & $92 \pm 8$ \\
\hline & 18.7 & $100 \pm 10$ & $111 \pm 11$ & 10 & $98 \pm 10$ & $99 \pm 17$ \\
\hline \multirow{3}{*}{$\mathrm{PGF}_{2 \alpha}$} & 75 & $112 \pm 6$ & $96 \pm 5$ & 50 & $110 \pm 5$ & $112 \pm 14$ \\
\hline & 150 & $96 \pm 4$ & $101 \pm 7$ & 100 & $104 \pm 7$ & $105 \pm 16$ \\
\hline & 18.7 & $81 \pm 8$ & $80 \pm 15$ & 10 & $94 \pm 13$ & $78 \pm 13$ \\
\hline \multirow[t]{2}{*}{ 1a,1b-dihomo-PGF $2 \alpha^{\mathrm{b}}$} & 75 & $83 \pm 9$ & $93 \pm 11$ & 50 & $95 \pm 7$ & $72 \pm 9$ \\
\hline & 150 & $120 \pm 7$ & $120 \pm 7$ & 100 & $120 \pm 9$ & $109 \pm 9$ \\
\hline & 16.9 & $102 \pm 4$ & $84 \pm 10$ & 8.6 & $88 \pm 14$ & $107 \pm 15$ \\
\hline $7(R S)-S T-\Delta^{8}-11-$ & 67.5 & $94 \pm 9$ & $101 \pm 10$ & 45 & $104 \pm 20$ & $90 \pm 20$ \\
\hline & 135 & $110 \pm 6$ & $96 \pm 11$ & 90 & $105 \pm 5$ & $112 \pm 10$ \\
\hline & 17.7 & $91 \pm 8$ & $97 \pm 8$ & 9 & $120 \pm 3$ & $90 \pm 10$ \\
\hline 10-epi-10-F $\mathrm{F}_{4 \mathrm{t}}-\mathrm{NeuroP}$ & 70.8 & $98 \pm 3$ & $96 \pm 10$ & 47.2 & $81 \pm 3$ & $94 \pm 8$ \\
\hline & 142 & $102 \pm 9$ & $102 \pm 7$ & 94.4 & $93 \pm 12$ & $102 \pm 9$ \\
\hline & 17.7 & $89 \pm 8$ & $102 \pm 10$ & 9 & $104 \pm 14$ & $84 \pm 15$ \\
\hline $4(R S)-\mathrm{F}_{4 \mathrm{t}}-$ NeuroP & 70.8 & $99 \pm 4$ & $94 \pm 7$ & 47.2 & $95 \pm 10$ & $80 \pm 11$ \\
\hline & 142 & $112 \pm 6$ & $99 \pm 8$ & 94.4 & $95 \pm 6$ & $80 \pm 9$ \\
\hline & 17.5 & $107 \pm 6$ & $80 \pm 6$ & 8.9 & $116 \pm 6$ & $81 \pm 8$ \\
\hline 17-epl-17- $\mathrm{F}_{2 \mathrm{t}}-\mathrm{dihomo-}$ & 70.2 & $87 \pm 6$ & $87 \pm 7$ & 46.8 & $80 \pm 10$ & $88 \pm 6$ \\
\hline & 140 & $105 \pm 8$ & $105 \pm 9$ & 93.6 & $113 \pm 10$ & $116 \pm 7$ \\
\hline & 17.5 & $75 \pm 8$ & $111 \pm 10$ & 8.9 & $70 \pm 9$ & $95 \pm 7$ \\
\hline $17-\mathrm{F}_{2 \mathrm{t}}$-dihomo-IsoP $\mathrm{P}^{\mathrm{b}}$ & 70.0 & $98 \pm 10$ & $98 \pm 12$ & 46.6 & $106 \pm 16$ & $106 \pm 19$ \\
\hline & 140 & $109 \pm 6$ & $108 \pm 10$ & 93.2 & $108 \pm 16$ & $108 \pm 19$ \\
\hline & 17 & $82 \pm 10$ & $84 \pm 11$ & 8.6 & $105 \pm 15$ & $80 \pm 20$ \\
\hline $17(R S)-10-e p l-S C-\Delta^{1 J}$ & 67.5 & $81 \pm 2$ & $84 \pm 8$ & 45 & $100 \pm 9$ & $81 \pm 12$ \\
\hline 11-dihomo-lsoF & 135 & $114 \pm 5$ & $92 \pm 3$ & 90 & $114 \pm 12$ & $106 \pm 15$ \\
\hline & 17.5 & $107 \pm 2$ & $118 \pm 15$ & 8.9 & $117 \pm 12$ & $107 \pm 10$ \\
\hline Ent- $/(R S)-7-\mathrm{F}_{2 \mathrm{t}^{-}}$ & 70.2 & $107 \pm 3$ & $106 \pm 6$ & 46.8 & $90 \pm 8$ & $109 \pm 20$ \\
\hline dihomo-IsoP & 140 & $114 \pm 9$ & $119 \pm 10$ & 93.6 & $118 \pm 4$ & $100 \pm 10$ \\
\hline & 17.7 & $90 \pm 10$ & $80 \pm 10$ & 9 & $97 \pm 9$ & $100 \pm 20$ \\
\hline $14(R S)-14-\mathrm{F}_{4 \mathrm{t}}-$ NeuroP & 70.8 & $100 \pm 4$ & $105 \pm 6$ & 47.2 & $120 \pm 9$ & $108 \pm 19$ \\
\hline & 142 & $100 \pm 9$ & $110 \pm 9$ & 94.4 & $94 \pm 10$ & $93 \pm 18$ \\
\hline
\end{tabular}

a Saliva samples subjected to UA-LLsME as sample treatment.

b Quantification in saliva samples using standards subjected to UA-LLsME.

\subsection{Analyte stability study}

The analytes' stability assessment in saliva samples spiked at medium concentration level was carried out after several freezethaw cycles (long-term stability), and after $24 \mathrm{~h}$ at $4{ }^{\circ} \mathrm{C}$ (short-term stability). These samples were analyzed by triplicate, and the found concentrations were compared with results from freshly prepared solutions. In general, the recoveries were between 80 and $125 \%$. Therefore, the analytes did not suffer from any significant deterioration.

\subsection{Application to samples}

The applicability of the new developed analytical method was assayed analyzing 30 saliva samples from elderly people with neurodegenerative diseases. Some analytes (5- $\mathrm{F}_{2 \mathrm{t}}$-IsoP, 15-keto-

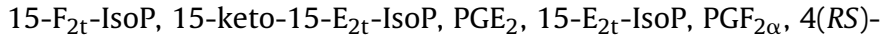
$\mathrm{F}_{4 \mathrm{t}}$-NeuroP, 7(RS)-ST- $\Delta^{8}$-11-dihomo-IsoF, 10-epi-10- $\mathrm{F}_{4 \mathrm{t}}-\mathrm{NeuroP}$ and $14(R S)-14-\mathrm{F}_{4 \mathrm{t}}-\mathrm{NeuroP}$ ) were detected in all the saliva samples (Table 5), indicating the suitable analytical method sensitivity. In addition, signals from total parameters (IsoPs, NeuroPs, IsoFs, NeuroFs) were detected in saliva samples. These results are expressed 
Table 5

Concentrations found for each compound in saliva samples from participants.

\begin{tabular}{|c|c|c|}
\hline \multirow[t]{2}{*}{ Analyte } & \multicolumn{2}{|c|}{$\begin{array}{l}\text { Saliva samples }(\mathrm{n}=30) \\
\left(\mathrm{ng} \mathrm{m \textrm {m } ^ { - 1 }} \text { protein }\right)\end{array}$} \\
\hline & Median & $\mathrm{IQR}^{\mathrm{a}}(\mathrm{Q} 1-\mathrm{Q} 3)$ \\
\hline $15(R)-15-\mathrm{F}_{2 \mathrm{t}}-\mathrm{IsoP}$ & 0.04 & $0.03-0.2$ \\
\hline 1a,1b-dihomo-PGF $2 \alpha$ & 0.56 & $0.35-1.16$ \\
\hline 2,3-dinor-15-epi-15- $\mathrm{F}_{2 \mathrm{t}}$-IsoP & $<$ LOD & - \\
\hline 15-keto-15-F ${ }_{2 t}$-IsoP & 0.04 & $0.02-0.13$ \\
\hline 15-keto-15- $\mathrm{E}_{2 \mathrm{t}}$-IsoP & 0.09 & $0.02-0.18$ \\
\hline $\mathrm{PGE}_{2}$ & 0.25 & $0.14-0.42$ \\
\hline $15-\mathrm{E}_{2 \mathrm{t}}-\mathrm{IsoP}$ & 0.09 & $0.04-0.15$ \\
\hline $15-F_{2 t}$-IsoP & $<$ LOD & $<$ LOD -0.01 \\
\hline $\mathrm{PGF}_{2 \alpha}$ & 0.24 & $0.17-0.37$ \\
\hline $4(R S)-\mathrm{F}_{4 \mathrm{t}}-$ NeuroP & 0.12 & $0-0.66$ \\
\hline 7(RS)-ST- $\Delta^{8}$-11-dihomo-IsoF & 0.3 & $0.12-0.42$ \\
\hline $5-\mathrm{F}_{2 \mathrm{t}}-\mathrm{IsoP}$ & 0.11 & $0.05-0.24$ \\
\hline 10-epi-10- $\mathrm{F}_{4 \mathrm{t}}-\mathrm{NeuroP}$ & 0.1 & $0.06-0.3$ \\
\hline 17-epi-17-F Ft -dihomo-IsoP & 0.17 & $0.04-0.3$ \\
\hline $17-\mathrm{F}_{2 \mathrm{t}}$-dihomo-IsoP & 0.25 & $0.09-0.54$ \\
\hline $17(R S)$-10-epi-SC- $\Delta^{15}$-11-dihomo-IsoF & 0.2 & $0.09-0.49$ \\
\hline Ent-7(RS)-7- $\mathrm{F}_{2 \mathrm{t}}$-dihomo-IsoP & 0.05 & $0.01-0.49$ \\
\hline $14(R S)-14-\mathrm{F}_{4 \mathrm{t}}-$ NeuroP & 0.62 & $0.28-3.96$ \\
\hline NeuroPs ${ }^{b}$ & 0.23 & $<$ LOD-0.037 \\
\hline IsoPs $^{b}$ & 0.17 & $0.1-0.28$ \\
\hline NeuroFs ${ }^{b}$ & 0.22 & $0.05-0.86$ \\
\hline $\mathrm{IsoFs}^{\mathrm{b}}$ & 0.16 & $0.1-0.44$ \\
\hline
\end{tabular}

a IQR: interquartile range.

b Total parameters results are expressed as (analyte signal intensity / (internal standard signal intensity)) $\mathrm{mg}^{-1}$ of protein in saliva samples.

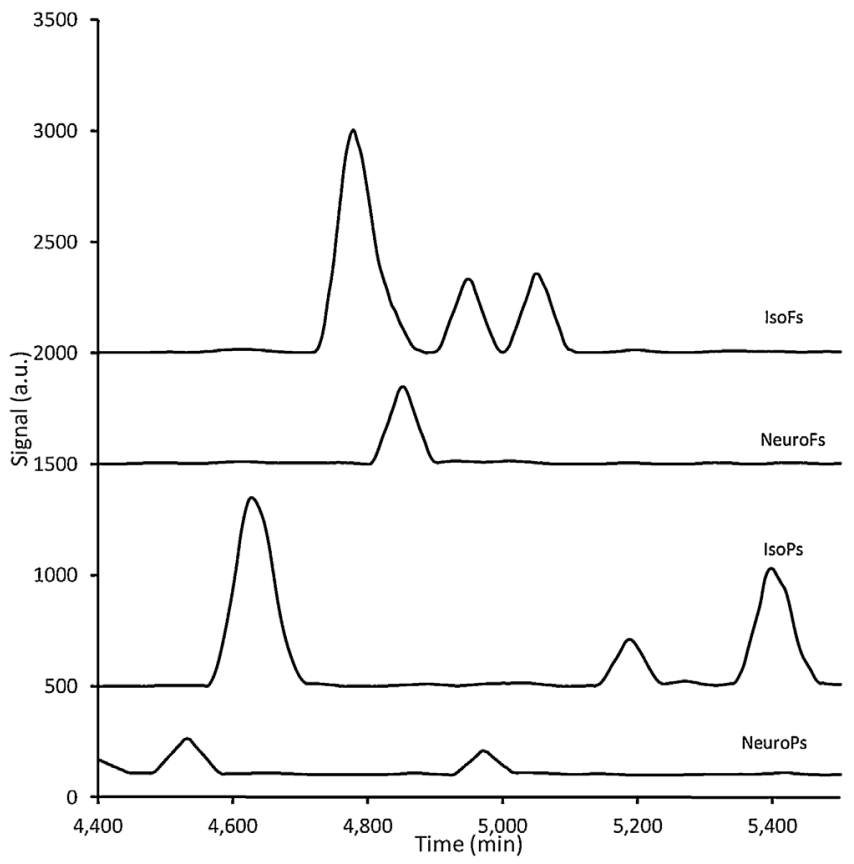

Fig. 2. UPLC-MS/MS chromatograms obtained with the validated method for total parameters (IsoFs, NeuroFs, IsoPs, NeuroPs) found in saliva samples from patients with neurodegenerative disease.

as (analyte signal intensity / (internal standard signal intensity)) $\mathrm{mg}^{-1}$ of protein. As an illustrative example, Fig. 2 shows the chromatograms corresponding to total parameters found in patients' saliva samples.

\section{Conclusions}

A new and simple analytical method based on liquid-liquid extraction followed by UPLC-MS/MS has been developed to determine simultaneously 18 analytes (F2-IsoPs, prostaglandins,
F4-NeuroPs, F2-dihomo-IsoPs, dihomo-IsoFs) and 4 total parameters (IsoPs, NeuroPs, IsoFs, NeuroFs) in limited volume saliva samples. This method showed suitable sensitivity, as well as satisfactory precision and accuracy to be applied to saliva samples from patients with different neurodegenerative pathologies, in which lipid peroxidation could play an important role. This new set of lipid peroxidation biomarkers has not been previously measured in saliva samples, and the lack of validated analytical methods adds relevance to this work.

Nevertheless, further work analysing a higher number of saliva samples from well-defined groups of participants, and using the developed analytical method is required, in order to evaluate these analytes as potential salivary biomarkers in a specific neurodegenerative disease.

\section{Funding}

This work was supported by the Instituto de Salud Carlos III (Miguel Servet I Project (CP16/00082)) (Spanish Ministry of Economy and Competitiveness), and RETICS funded by the PN 2018-2011 (Spain), ISCIII- Sub-Directorate General for Research Assessment and Promotion and the European Regional Development Fund (FEDER), reference RD16/0022.

\section{Conflicts of interest}

None of the authors of this manuscript declares having conflicts of interest.

\section{Acknowledgments}

We are greatly indebted to all participants, nursing and medical staff who voluntarily participated in the present study. Without their collaboration and enthusiasm this study could not have been completed.

CC-P acknowledges a "Miguel Servet I" Grant(CP16/00082) from the ISCIII (Spanish Ministry of Economy and Competitiveness). MV acknowledges RETICS funded by the PN 2018-2011 (Spain), ISCIIISub-Directorate General for Research Assessment and Promotion and the European Regional Development Fund (FEDER), reference RD16/0022; CC-P acknowledges a post-doctoral Grant (associated to "Miguel Servet" project CP16/00082) from the Instituto Carlos III (Spanish Ministry of Economy, Industry and Competitiveness).

\section{References}

[1] W.J. Huang, X. Zhang, W.W. Chen, Role of oxidative stress in Alzheimer's disease, Biomed. Rep. 4 (2016) 519-522.

[2] R.M. Adibhatla, J.F. Hatcher, Lipid oxidation and peroxidation in CNS health and disease: from molecular mechanisms to therapeutic opportunities, Antioxid. Redox Signal. 12 (2010) 125-169.

[3] E. Miller, A. Morel, L. Saso, J. Saluk, Isoprostanes and neuroprostanes as biomarkers of oxidative stress in neurodegenerative diseases, Oxid. Med. Cell. Longev. (2014) 1-10.

[4] M. Choromańska, A. Klimiuk, P. Kostecka-Sochoń, K. Wilczyńska, M. Kwiatkowski, N. Okuniewska, N. Waszkiewicz, A. Zalewska, M. Maciejczyk, Antioxidant defence, oxidative stress and oxidative damage in saliva, plasma and erythrocytes of dementia patients. Can salivary age be a marker of dementia? Int. J. Mol. Sci. 18 (2017).

[5] F. Bermejo-Pareja, D. Antequera, T. Vargas, J.A. Molina, E. Carro, Saliva levels of Abeta1-42 as potential biomarker of Alzheimer's disease: a pilot study, BMC Neurol. 10 (2010) 108.

[6] N.H. Al-Rawi, A.M. Shahid, Oxidative stress, antioxidants, and lipid profile in the serum and saliva of individuals with coronary heart disease: is there a link with periodontal health? Minerva Stomatol. 66 (2017) 212-225.

[7] C. Arana, A.M. Moreno-Fernández, G. Gómez-Moreno, C. Morales-Portillo, I. Serrano-Olmedo, M.C. de la Cuesta Mayor, T. Martín Hernández, Increased. salivary oxidative stress parameters in patients with type 2 diabetes: relation with periodontal disease, Endocrinol. Diabetes Nutr. 64 (2017) 258-264

[8] T. Pfaffe, J. Cooper-White, P. Beyerlein, K. Kostner, C. Punyadeera, Diagnostic potential of saliva: current state and future applications, Clin. Chem. 57 (2011), 675687

[9] A. Yilmaz, T. Geddes, B. Han, R.O. Bahado-Singh, G.D. Wilson, K. Imam, M. Maddens, S.F. Graham, Diagnostic biomarkers of Alzheimer's disease as 
identified in saliva using $1 \mathrm{H}$ NMR-Based metabolomics, J. Alzheimers Dis. 58 (2017) 355-359

[10] Y. Huang, M. Zhu, Z. Li, R. Sa, Q. Chu, Q. Zhang, H. Zhang, W. Tang, M. Zhang, H. Yin, Mass spectrometry-based metabolomics profiling identifies alterations in salivary redox status and fatty acid metabolism in response to inflammation and oxidative stress in periodontal disease, Free Rad. Biol. Med. 70 (2014) 223-232.

[11] A. Mansourian, F. Agha-Hosseini, H.H. Kazemi, N. Mortazavi, M.S. Moosavi, J. Beytollahi, I. Mirzaii-Dizgah, Salivary oxidative stress in oral lichen planus treated with triamcinolone mouthrinse, Dent. Res. J. 14 (2017) 104-110.

[12] Y.H. Lee, D.T. Wong, Saliva: an emerging biofluid for early detection of diseases, Am. J. Dent. 22 (2009) 241-248.

[13] Y.C. Hsu, B.G. Chen, S.C. Yang, Y.S. Wang, S.P. Huang, M.H. Huang, T.J. Chen, H.C. Liu, D.L. Lin, R.H. Liu, A.W. Jones, Methadone concentrations in blood, plasma, and oral fluid determined by isotope-dilution gas chromatography-mass spectrometry, Anal. Bioanal. Chem. 405 (2013) 3921-3928.

[14] R. Metgud, S. Bajaj, Evaluation of salivary and serum lipid peroxidation, and glutathione in oral leukoplakia and oral squamous cell carcinoma, J. Oral Sci. 56 (2014) 135-142.

[15] E. Baltacıoğlu, P. Yuva, G. Aydın, A. Alver, C. Kahraman, E. Karabulut, F.A. Akalın, Lipid peroxidation levels and total oxidant/antioxidant status in serum and saliva from patients with chronic and aggressive periodontitis. Oxidative stress index: a new biomarker for periodontal disease? J. Periodontol. 85 (2014) 1432-1441.

[16] T.T. Nguyen, L.Q. Ngo, A. Promsudthi, R. Surarit, Salivary lipid peroxidation in patients with generalized chronic periodontitis and acute coronary syndrome, J. Periodontol. 87 (2016) 134-141.

[17] D. Darczuk, W. Krzysciak, P. Vyhouskaya, B. Kesek, D. Galecka-Wanatowicz, W. Lipska, T. Kaczmarzyk, M. Gluch-Lutwin, B. Mordyl, M. Chomyszyn-Gajewska, Salivary oxidative status in patients with oral lichen planus, Physiol. Pharmacol. 67 (2016) 885-894.

[18] T.T. Nguyen, L.Q. Ngo, A. Promsudthi, R. Surarit, Salivary oxidative stress biomarkers in chronic periodontitis and acute coronary syndrome, Clin. Oral Investig. 21 (2017) 2345-2353.

[19] H. Su, M. Gornitsky, G. Geng, A.M. Velly, H. Chertkow, H.M. Schipper, Diurnal variations in salivary protein carbonyl levels in normal and cognitively impaired human subjects, Age (Dordr) 30 (2018) 1-9.

[20] J.A. Oh, H.S. Shin, Simple and sensitive determination of malondialdehyde in human urine and saliva using UHPLC-MS/MS after derivatization with 3,4-diaminobenzophenone, J. Sep. Sci. 40 (2017) 3958-3968.

[21] A. Bulatov, K. Medinskaia, D. Aseeva, S. Garmonov, L. Moskvin, Determination of antipyrine in saliva using the dispersive liquid-liquid microextraction based on a stepwise injection system, Talanta 133 (2015) 66-70.

[22] I. Timofeeva, K. Medinskaia, L. Nikolaeva, D. Kirsanov, A. Bulatov, Stepwise injection potentiometric determination of caffeine in saliva using single-drop microextraction combined with solvent exchange, Talanta 150 (2016) $655-660$.
[23] A. Esrafili, Y. Yamini, M. Ghambarian, B. Ebrahimpour, Automated preconcentration and analysis of organic compounds by on-line hollow fibe liquid-phase microextraction-high performance liquid chromatography, J. Chromatogr. A 1262 (2012) 27-33.

[24] L.K. Xue, W.W. Ma, D.X. Zhang, X.Z. Du, Ultrasound assisted liquid-liquid microextraction based on an ionic liquid for preconcentration and determination of UV filters in environmental water samples, Anal. Methods 5 (2013) 4213-4219.

[25] Y. Jiao, J. Yu, Y. Yang, Vortex-assisted liquid-liquid microextraction combined with spectrophotometry for the determination of trace nitrite in water samples, Water Sci. Technol. 17 (2017) 1225-1231.

[26] M.S. Albert, S.T. DeKosky, D. Dickson, B. Dubois, H.H. Feldman, N.C. Fox, A. Gamst, D.M. Holtzman, W.J. Jagust, R.C. Petersen, P.J. Snyder, M.C. Carrillo, B. Thies, C.H. Phelps, The diagnosis of mild cognitive impairment due to Alzheimer's disease: recommendations from the National Institute on Aging-Alzheimer's Association workgroups on diagnostic guidelines for Alzheimer's disease, Alzheimers Dement. 7 (2011) 270-279.

[27] C. Cháfer-Pericás, I. Torres-Cuevas, A. Sanchez-Illana, J. Escobar, J. Kuligowski, R. Solberg, H.T. Garberg, M.U. Huun, O.D. Saugstad, M. Vento, Development of a reliable analytical method to determine lipid peroxidation biomarkers in newborn plasma samples, Talanta 153 (2016) 152-157.

[28] A. de la Torre, Y.Y. Lee, A. Mazzoni, A. Guy, V. Bultel-Poncé, T. Durand, C. Oger J.C. Lee, J.M. Galano, Total syntheses and in vivo quantitation of nove neurofuran and dihomo-isofuran derived from docosahexaenoic acid and adrenic acid, Chemistry 21 (2015) 2442-2446.

[29] A. García-Blanco, C. Peña-Bautista, C. Oger, C. Vigor, J.M. Galano, T. Durand, N. Martín-Ibáñez, M. Baquero, M. Vento, C. Cháfer-Pericás, Reliable determination of new lipid peroxidation compounds as potential early Alzheimer Disease biomarkers, Talanta 184 (2018) 193-201.

[30] C. Peña-Bautista, C. Vigor, J.M. Galano, C. Oger, T. Durand, I. Ferrer, A. Cuevas, R. López-Cuevas, M. Baquero, M. López-Nogueroles, M. Vento, D. Hervás, A García-Blanco, C. Cháfer-Pericás, Plasma lipid peroxidation biomarkers for early and non-invasive Alzheimer Disease detection, Free Rad. Biol. Med. 124 (2018) 388-394.

[31] A. García-Blanco, M. Vento, V. Diago, C. Cháfer-Pericás, Reference ranges for cortisol and $\alpha$-amylase in mother and newborn saliva samples at different perinatal and postnatal periods, J. Chromatogr. B Analyt. Technol. Biomed. Life Sci. 1022 (2016) 249-255.

[32] D. Jain, R. Athawale, A. Bajaj, S. Shrikhande, Double- salting out assisted liquid-liquid extraction (SALLE) HPLC method for estimation of Temozolomide from biological samples, J. Chromatogr. B Analyt. Technol. Biomed. Life Sci. 970 (2014) 86-94.

[33] Z. Wu, W. Gao, M.A. Phelps, D. Wu, D.D. Miller, J.T. Dalton, Favorable effects of weak acids on negative-ion electrospray ionization mass spectrometry, Anal Chem. 76 (2004) 839-847. 